\title{
Curcumin combined with FAPac vaccine elicits effective antitumor response by targeting indolamine-2,3-dioxygenase and inhibiting EMT induced by TNF-a in melanoma
}

\author{
Guan-Min Jiang ${ }^{1, *}$, Wan-Ying Xie ${ }^{2, *}$, Hong-Sheng Wang ${ }^{3, *}$, Jun $\mathrm{Du}^{3}$, Bai-Ping Wu ${ }^{1}$, \\ Wei Xu${ }^{2}$, Hui-Fang Liu ${ }^{2}$, Ping Xiao, ${ }^{1}$, Zhi-Gang Liu ${ }^{4}$, Hong-Yan Li ${ }^{1}$, Shuang-Quan \\ Liu $^{2}$, Wen-Jun Yin ${ }^{2}$, Qiu-Gui Zhang ${ }^{2}$, Jian-Ping Liang ${ }^{5}$, Hong-Jun Huang ${ }^{1}$ \\ ${ }^{1}$ Department of Clinical Laboratory, Hunan Cancer Hospital \& The Affiliated Cancer Hospital of Xiangya School of Medicine, \\ Central South University, Changsha, 410013, PR China \\ ${ }^{2}$ Department of Clinical Laboratory, The First Affiliated Hospital of University of South China, Hengyang, 421001, PR China \\ ${ }^{3}$ Department of Microbial and Biochemical Pharmacy, School of Pharmaceutical Sciences, Sun Yat-sen University, Guangzhou, \\ 510006, PR China \\ ${ }^{4}$ Department of Radiation Oncology, Hunan Cancer Hospital \& The Affiliated Cancer Hospital of Xiangya School of Medicine, \\ Central South University, Changsha, 410013, PR China \\ ${ }^{5}$ Department of Thoracic Surgery 2, Hunan Cancer Hospital \& The Affiliated Cancer Hospital of Xiangya School of Medicine, \\ Central South University, Changsha, 410013, PR China \\ *These authors have contributed equally to this work
}

Correspondence to:

Hong-Jun Huang, e-mail: hongjunhuanghjh@163.com

Jian-Ping Liang, e-mail: liangsugd@vip.sina

Qiu-Gui Zhang, e-mail: zhangqg789@163.com

Keywords: curcumin, indolamine-2,3-dioxygenase, immunotherapy, melanoma, fibroblast activation protein a

Published: July 20, 2015

\section{ABSTRACT}

Fibroblast activation protein a (FAPa) is a potential target for cancer therapy. However, elimination of FAPa+ fibroblasts activates secretion of IFN-Y and TNF-a. IFN-Y can in turn induce expression indolamine-2,3-dioxygenase (IDO), thereby contributing to immunosuppression, while TNF-a can induce EMT. These two reactive effects would limit the efficacy of a tumor vaccine. We found that curcumin can inhibit IDO expression and TNF-a-induced EMT. Moreover, FAPac vaccine and CpG combined with curcumin lavage inhibited tumor growth and prolonged the survival of mice implanted with melanoma cells. The combination of FAPac vaccine, CpG and curcumin stimulated FAPa antibody production and CD8 + T cell-mediated killing of FAPa-expressing stromal cells without adverse reactive effects. We suggest a combination of curcumin and FAPac vaccine for melanoma therapy.

\section{INTRODUCTION}

Melanoma is the most serious form of skin cancer. Historically, metastatic melanoma has carried a poor prognosis, but recently new and potentially more effective anti-CTLA4 and anti-PD-1 therapies, as well as other immunotherapies, have shown promise [1,2]. However, a major impediment to cancer immunotherapy is the induction of indolamine-2,3-dioxygenase (IDO), which is a key mediator of tumor immune tolerance [3]. IDO is the first and rate-limiting enzyme in the metabolism of the essential amino acid tryptophan along the kynurenine pathway. It induces immune tolerance by depleting tryptophan locally and producing toxic tryptophan catabolites that induce proliferation arrest, inactivation and apoptosis among $\mathrm{T}$ lymphocytes and natural killer (NK) cells $[4,5]$. Thus, inhibition of IDO expression and/or activity is considered to be a potentially effective therapeutic strategy $[6,7]$.

Given the close interaction between tumor cells and cancer-associated fibroblasts (CAFs) in the tumor microenvironment, CAF-targeted strategies could also make an important contribution to an integrated cancer immunotherapy [8]. Fibroblast activation protein $\alpha$ $(\mathrm{FAP} \alpha)$ is a serine protease involved in extracellular matrix remodeling and is strongly expressed by CAFs, 
but is not detectable in normal adult human tissues [9, 10]. Furthermore, because of the multiple roles played by FAP $\alpha$ in neoangiogenesis, invasion and metastasis, it is frequently explored as a target for cancer therapy. In the context of immunotherapy involving $\mathrm{T}$ cells targeting cancer cells, an agent targeting FAP $\alpha$-expressing cells might increase therapeutic efficacy against both solid tumors and metastatic cells $[11,12]$. Removing FAP $\alpha+$ fibroblasts does not alter the number or subtypes of tumor infiltrating $\mathrm{T}$ cells, but does result in their activation and secretion of interferon- $\gamma$ (IFN- $\gamma$ ) and tumor necrosis factor- $\alpha$ (TNF- $\alpha$ ), two antitumor cytokines secreted by activated Th1 and NK cells [13]. On the other hand, IFN- $\gamma$ also strongly induces expression of IDO, which reportedly contributes to tumorinduced immunosuppression [14], while TNF- $\alpha$ can induce epithelial-mesenchymal transition (EMT), an important contributor to cancer invasion and metastasis [15-18]. Together, the induction of IDO expression and EMT limit the therapeutic efficacy of antitumor vaccines.

Curcumin is a natural polyphenolic compound derived from the root of curcuma longa, which is widely used for medical purposes in India. A large body of evidence from in vitro and in vivo studies in both animals and human indicate that curcumin exerts antioxidant, antiinflammatory, antitumor, antifibrotic and wound healing properties [19, 20]. Moreover, we previously showed that curcumin can inhibit the IDO expression induced by IFN- $\gamma$ and the EMT induced by TNF- $\alpha$, suggesting curcumin could be a useful agent for antitumor therapy when combined with tumor vaccines.

In our present work, we assessed the therapeutic efficacy and molecular mechanism of a combination of curcumin with FAP $\alpha$ c vaccine, which contains the main catalytic domain of the dipeptidyl peptidase of FAP $\alpha$ with abundant T-cell and B-cell epitopes. In addition, we also administered the Th1-polarized immunoregulator $\mathrm{CpG}$ oligonucleotide 1826, which was previously shown to enhance specific cellular and humoral immune responses in C57 mice [21]. It was anticipated that this new approach would eliminate the immune tolerance and tumor cell metastasis induced by IFN- $\gamma$ and TNF- $\alpha$. Our results show that FAP $\alpha$ c vaccine in combination with curcumin inhibits tumor growth and significantly prolongs the survival of mice implanted with B16 melanoma cells. These findings suggest combination therapy using FAP $\alpha$ c vaccine in combination with curcumin may be an effective approach to preventing and treating melanoma.

\section{RESULTS}

\section{Curcumin dose-dependently down-regulates IDO expression in B16 melanoma cells}

To investigate the effect of curcumin on IDO expression, B16 melanoma cells were first pretreated for $4 \mathrm{~h}$ with selected concentrations of curcumin before treating the cells with IFN- $\gamma(100 \mathrm{U} / \mathrm{ml})$ for $24 \mathrm{~h}$. IDO expression was then assessed in total cell lysates using western blotting. As shown in Figure 2, treatment with curcumin significantly and dose-dependently reduced IDO expression, which was almost completely inhibited at a concentration of $25 \mu \mathrm{M}$ (Figure 2). More importantly, curcumin not only inhibited IDO expression induced by IFN- $\gamma$, it also suppressed basal expression of IDO in B16 cells. But because the majority of B16 exposed to $25 \mu \mathrm{M}$ curcumin died, in subsequent experiments we applied curcumin at a concentration of $15 \mu \mathrm{M}$, which downregulated IDO expression significantly but did not affect the survival rate of the cells (Figure $2 \mathrm{~A}-2 \mathrm{~B}$ ). Overall, this result demonstrates that curcumin downregulates IFN- $\gamma$-induced and basal expression of IDO in a dose-dependent manner.

\section{Treatment schema}

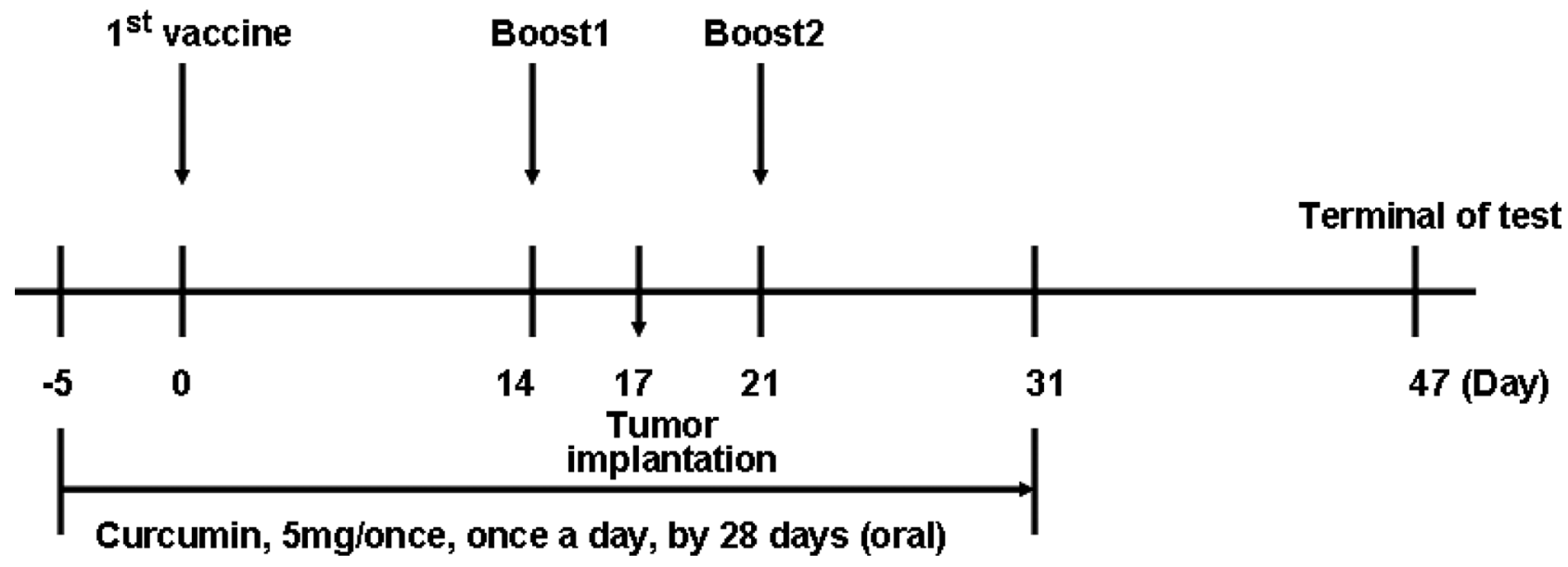

Figure 1: Schematic representation of the treatment schedule and dosages in mice. 


\section{Curcumin suppresses TNF- $\alpha$-induced EMT in B16 melanoma cells}

As mentioned, TNF- $\alpha$ has been shown to induce EMT in several cell lines. To verify that effect in B16 cells, we treated the cells with TNF- $\alpha(20 \mathrm{ng} / \mathrm{ml})$ and recorded the phenotypic changes using a phase contrast microscope. After treatment with TNF- $\alpha$ for $72 \mathrm{~h}, \mathrm{~B} 16$ cells became scattered and adopted the typical fibroblastlike morphology of mesenchymal cells (Figure 3A). In addition, up-regulation of vimentin and down-regulation of E-cadherin are important molecular markers of EMT. TNF- $\alpha$-treated cells in the present study exhibited significantly up-regulated vimentin expression and downregulated E-cadherin expression (Figure 3B-3C). Taken together, these results indicate that TNF- $\alpha$ induces EMT in $\mathrm{B} 16$ cells.

To then evaluate the effect of curcumin on TNF$\alpha$-induced EMT, the cells were pretreated for $4 \mathrm{~h}$ with or without curcumin $(15 \mu \mathrm{M})$ before treatment for $72 \mathrm{~h}$ with or without TNF- $\alpha(20 \mathrm{ng} / \mathrm{ml})$. Phenotypic changes were then recorded using a phase contrast microscope, and vimentin and E-cadherin expression was assessed using western blotting. We found that in the absence of curcumin TNF- $\alpha$-treated cells exhibited morphological changes characteristic of EMT as well as a significant increase in vimentin levels and a corresponding decrease in E-cadherin levels. By contrast, the morphological changes induced by TNF- $\alpha$ were not observed in cells pretreated with curcumin, and the vimentin and E-cadherin levels were similar to those in the control group (Figure 3B-3C). This suggests that curcumin suppresses TNF- $\alpha$-induced EMT in B16 melanoma cells.

\section{IDO and FAP $\alpha$ were detectable in B16 tumor-bearing mice}

Because IDO is believed to be an important mediator of tumor immune tolerance that creates an immunosuppressive microenvironment within the tumor site, while the tumor-associated antigen FAP $\alpha$ plays multiple roles in neoangiogenesis, invasion and metastasis, we established an IDO- and FAP $\alpha$-expressing tumor model by implanting B16 cells into female C57 mice. We then performed immunohistochemical studies to determine whether IDO and FAP $\alpha$ were, in fact, expressed by the tumor tissues. As shown in Figure 4, we detected IDO expression in regions of B16 tumor tissue and FAP $\alpha$ expression in fibroblasts within the tumor stroma. These findings suggest that IDO-mediated immune tolerance occurs in B16 tumor-bearing mice, and FAP $\alpha$ is a useful target for tumor immunotherapy.
A

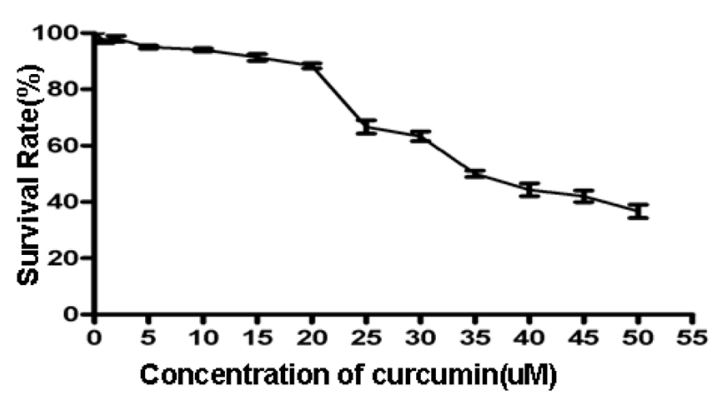

B

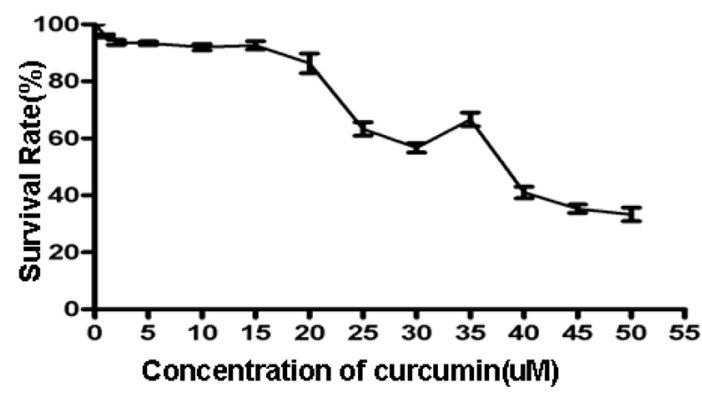

C

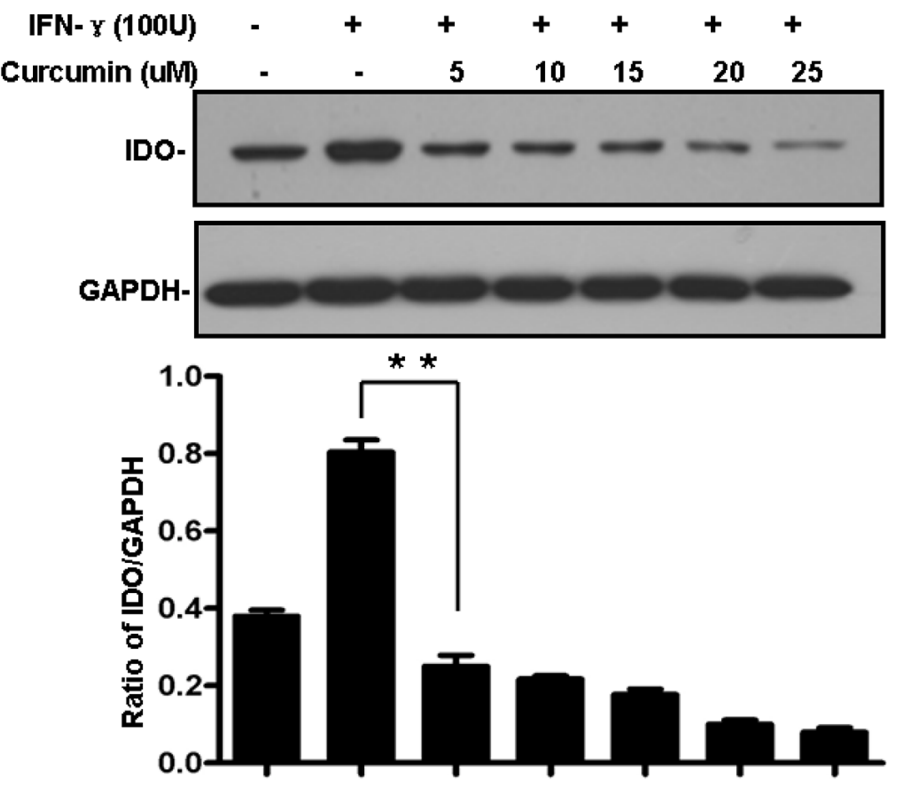

Figure 2: A, B. Cytotoxicity of curcumin in B16 cells. Experiments were performed by means of an MTT enzyme assay. B16 cells were incubated in the presence of different concentrations of curcumin at $37^{\circ} \mathrm{C}$ for $24 \mathrm{~h} \mathrm{(A)}$ or $48 \mathrm{~h}(\mathrm{~B})$ Each column represents the mean $\pm \mathrm{SD}$ with respect to $100 \%$ control. At least three independent assays were performed. C. Curcumin down-regulated the IFN- $\gamma$-induced expression of IDO in a dose-dependent manner. B16 cells were pretreated with the indicated concentrations of curcumin for $2 \mathrm{~h}$ and then treated with $100 \mathrm{U} / \mathrm{ml} \mathrm{IFN- \gamma}$ for $24 \mathrm{~h}$. IDO expression was detected by western blotting, GAPDH served as the loading control. Similar results were obtained in three independent experiments. 


\section{FAPac vaccine and CpG combined with} curcumin lavage elicits a protective antitumor response in a FAP $\alpha$-positive mice model

We demonstrated in vitro that curcumin downregulates IDO expression and suppresses TNF- $\alpha$-induced EMT (Figures 2 and 3). To assess the preventive efficacy of FAPac vaccine combined with curcumin in vivo, experiments were performed using a FAP $\alpha$-positive B16 tumor model. We found that 31 days after tumor implantation, the survival rate among mice immunized with FAP $\alpha c$ vaccine and $\mathrm{CpG}$ combined with curcumin lavage was $60 \%$, whereas the survival rates among mice immunized with $\mathrm{CpG}$ alone, with FAP $\alpha \mathrm{c}$ plus $\mathrm{CpG}$ or with curcumin plus $\mathrm{CpG}$ were all 20\% (Figure 5A). This suggests FAP $\alpha \mathrm{c}$ vaccine and $\mathrm{CpG}$ in combination with curcumin lavage elicits a protective antitumor response in FAP $\alpha$-positive B16 tumor-bearing mice. Consistent with that idea, the B16 tumor volume in mice treated with FAP $\alpha c$ vaccine and $\mathrm{CpG}$ combined with curcumin lavage was significantly smaller than in the other three groups 21 days after tumor implantation. During the period from 21 days to 31 days after tumor implantation, tumor volumes decreased sharply in all four groups, due to the development of ulcers (Figure 5C). In addition, the body weights of the mice in all four groups continued to increase, but there were no significant differences among the four groups (Figure 5B). Overall, these results suggest that the antitumor activity of the combination of FAP ac vaccine and $\mathrm{CpG}$ with curcumin lavage was significantly greater than $\mathrm{CpG}$ alone, curcumin plus $\mathrm{CpG}$ or even FAP $\alpha$ c vaccine plus $\mathrm{CpG}$.

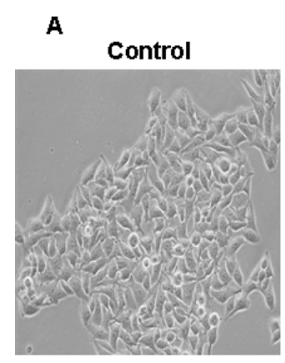

TNF-a (20ng/ml)+ Curcumin (15uM)

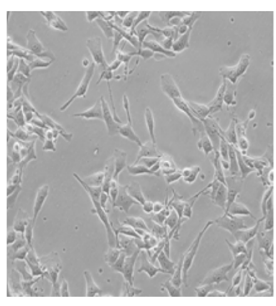

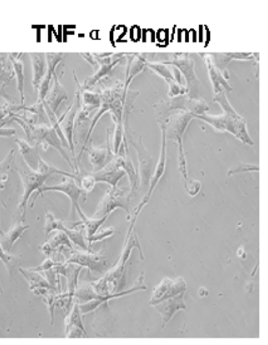

\section{Curcumin (15uM)}

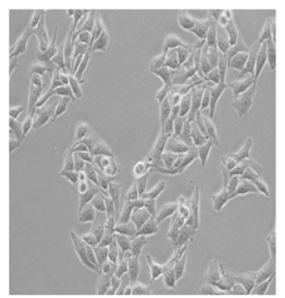

B
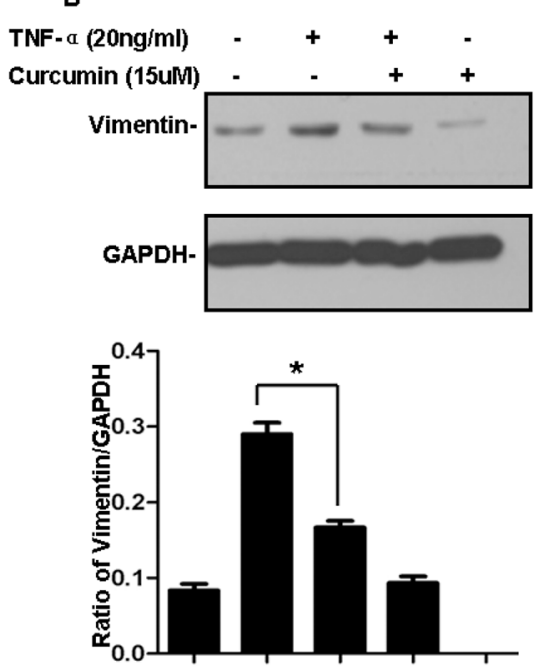

C
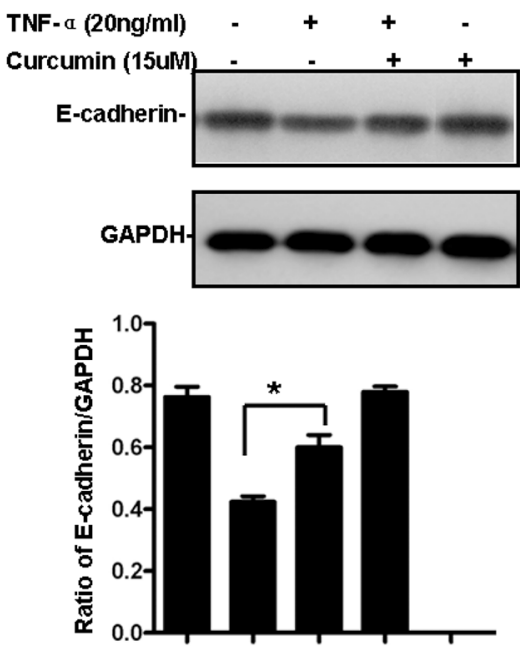

Figure 3: Curcumin inhibits TNF- $\alpha$-induced EMT in B16 cells. A. Cells were pre-treated with or without $15 \mu \mathrm{M}$ curcumin for $4 \mathrm{~h}$ and then treated with $20 \mathrm{ng} / \mathrm{ml} \mathrm{TNF- \alpha}$ for $72 \mathrm{~h}$. Phenotypic changes of EMT in B16 cells were detected using a phase contrast microscope. B, C. B16 cells were treated as indicated in (A) after which expression of vimentin (B) and E-cadherin (C) was detected by western blotting. GAPDH served as the loading control. Similar results were obtained in three independent experiments, ${ }^{*} p<0.05$.

\section{Negtive}

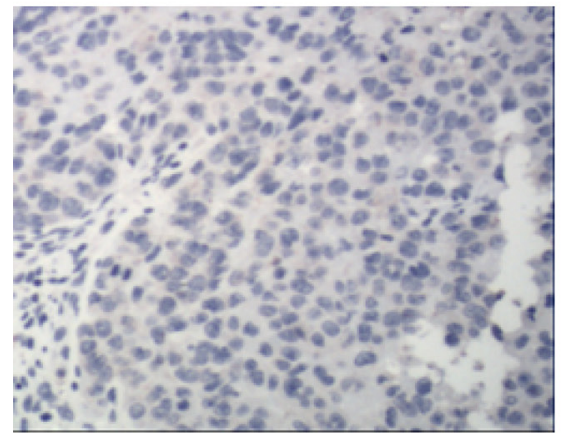

IDO

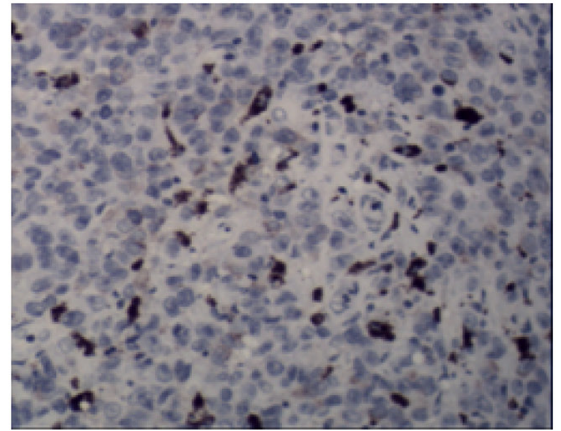

FAP a

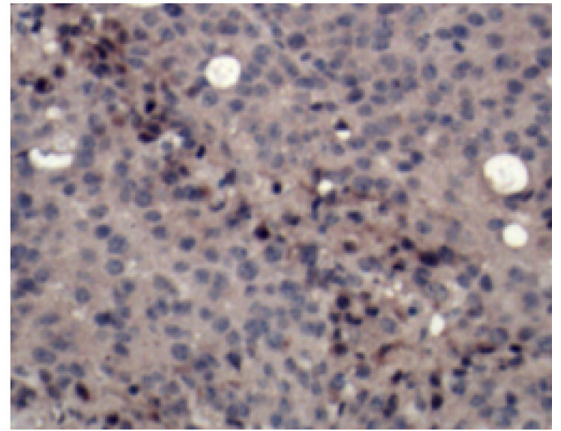

Figure 4: Identification of FAP $\alpha$ and IDO expression in B16 tumor cells of mice. Distributions of IDO and FAP $\alpha$ in B16 tumor tissue was examined immunohistochemically $(400 \times)$. IDO was observed in regions of B16 tumor cells, while FAP $\alpha$ was mainly detected in tumor stroma cells. 


\section{Antitumor mechanism of the FAPoc vaccine combined with curcumin}

To investigate the antitumor mechanism of FAP $\alpha \mathrm{c}$ vaccine combined with curcumin, we first performed immunohistochemical studies to verify the expression of IDO and FAP $\alpha$ within the tumor tissues. As shown in Figure 6, we found that in mice immunized with FAPac vaccine and $\mathrm{CpG}$ combined with curcumin lavage, the numbers of tumor cells expressing IDO and FAP $\alpha$ were significantly reduced and the tumor stroma was obviously destroyed (Figure 6C, red arrow). This indicates that curcumin abrogated the immune tolerance, most likely by suppressing IDO expression, enabling the FAP $\alpha \mathrm{c}$ vaccine to stimulate an important antitumor immune response in vivo. As shown in Figure 7A, mice immunized with FAP ac vaccine and $\mathrm{CpG}$ in combination with curcumin lavage exhibited a more significant humoral immune response than mice immunized with FAP $\alpha \mathrm{c}$ vaccine and $\mathrm{CpG}$ without curcumin (each group, $n=10 ; P<0.01$ ), though both groups elicited greater humoral immune responses than mice immunized with $\mathrm{CpG}$ alone or with curcumin plus $\mathrm{CpG}$ (each group, $n=10 ; P<0.01$ ).

This specific immune response was examined further using western blotting, which showed that the anti-FAP $\alpha$ antibody from individual immunized mice recognized FAP $\alpha$ protein in lysates of tumor tissue from B16 tumor-bearing mice. By contrast, no bands appeared when using the serum from mice immunized with PBS and $\mathrm{CpG}$ (Figure 7B). These data indicate that the FAP ac vaccine induces an antibody specific to the FAP $\alpha$ antigen.

To further explore the antitumor mechanism of FAP ac vaccine combined with curcumin, splenic CD8+ $\mathrm{T}$ cell function was examined. Splenocytes isolated from immunized mice were restimulated with FAP $\alpha \mathrm{c}$ for 3 days, after which IFN- $\gamma$ production by the CD8 $+\mathrm{T}$ cells was assessed using flow cytometry. As shown in Figure 7, we found that nearly $4.4 \%$ of the CD8+ T cells produced IFN- $\gamma$ in mice immunized with the FAP $\alpha \mathrm{c}$ vaccine and $\mathrm{CpG}$ combined with curcumin lavage. By contrast, only $0.9 \%$ of $\mathrm{CD} 8+\mathrm{T}$ cells in mice immunized with $\mathrm{CpG}$ alone, $0.9 \%$ in mice immunized with $\mathrm{CpG}$ and curcumin lavage, and $1.5 \%$ in mice immunized with FAP $\alpha c$ and CpG produced IFN- $\gamma$. These results suggest that the FAP $\alpha c$ vaccine and $\mathrm{CpG}$ combined with curcumin lavage elicited a protective antitumor response that was partially dependent on a curcumin-induced increase in FAP $\alpha$ antibody and $\mathrm{CD} 8+\mathrm{T}$ cell-mediated killing of FAP $\alpha-$ expressing tumor stromal cells.

\section{DISCUSSION}

Immunotherapy is poised to assume a more central role in the treatment of a variety of cancer types. Recognition of the immunogenic nature of melanoma has resulted in the development of several immunotherapeutic agents for its treatment, including ipilimumab and pembrolizumab, antibodies respectively blocking CTLA4 and PD-1 [22]. However, antigen selection remains a crucial step in tumor immunotherapy. It was recently suggested that tumor stromal cells could be a useful target for tumor immunotherapy because these cells, unlike the tumor cells, are diploid, genetically stable and susceptible to immunological attack [23].

Stromal cells and cancer cells depend on one another for mutual paracrine stimulation, and stromal CAFs are likely required for the survival and growth of cancer cells [24]. The transmembrane serine protease FAP $\alpha$ is highly expressed on the CAFs present in $>90 \%$ of human epithelial tumors, and plays a significant role in tumor progression and metastasis [25]. Targeting FAP $\alpha$ genetically or with vaccines or pharmacological agents has been shown to impair tumor progression in several preclinical cancer models [26, 27]. Consequently, FAP $\alpha$ is thought to be an adaptive tumor-associated antigen useful for tumor immunotherapy. In our research, we found that FAP $\alpha$ is stably expressed by the tumor stromal cells in B16 melanoma-bearing mice (Figure 4). The FAP ac peptide used in the present study is the main catalytic domain of the dipeptidyl peptidase of murine FAP $\alpha$ and contains abundant $\mathrm{T}$ cell and $\mathrm{B}$ cell epitopes, and is $96 \%$ homologous to the human FAP $\alpha$ homolog [28]. This suggests a FAP $\alpha \mathrm{c}$ vaccine could prove to be a valuable reference for clinical trials.

Although strategies targeting the immune system to achieve an antitumor response have shown promise in terms of survival benefit, the most common challenges encountered during immune-based antitumor therapy are lack of an antitumor immune response and frequent adverse events [29, 30]. For example, as mentioned above, the secretion of the antitumor cytokines IFN- $\gamma$ and TNF- $\alpha$ by activated Th1 and NK cells is a feature of effective tumor vaccines. Unfortunately, however, IFN- $\gamma$ can also induce IDO expression and TNF- $\alpha$ can induce EMT, limiting the development of a beneficial effect of therapy [13-15]. Here we found that these two adverse events also occur in B16 melanoma cells, and that these cells express IDO under basal conditions (Figures 2 and 3) and in the tumor tissue of B16 melanoma-bearing mice (Figure 4). This implies that IDO mediates immune tolerance in B16 tumor-bearing mice and suggests, therefore, that inhibiting induction of IDO expression and EMT could improve the efficacy of tumor vaccines. Notably, we found that curcumin inhibits both basal and IFN- $\gamma$-induced IDO expression and simultaneously represses TNF- $\alpha$-induced EMT in B16 melanoma cells (Figures2 and 3). Curcumin reportedly suppresses IFN- $\gamma$-induced IDO expression by blocking the Janus-activated kinase/protein kinase $\mathrm{C} \delta /$ STAT1 signaling pathway [31]. In addition, it also inhibits lipopolysaccharide-induced EMT in breast cancer cells 
A

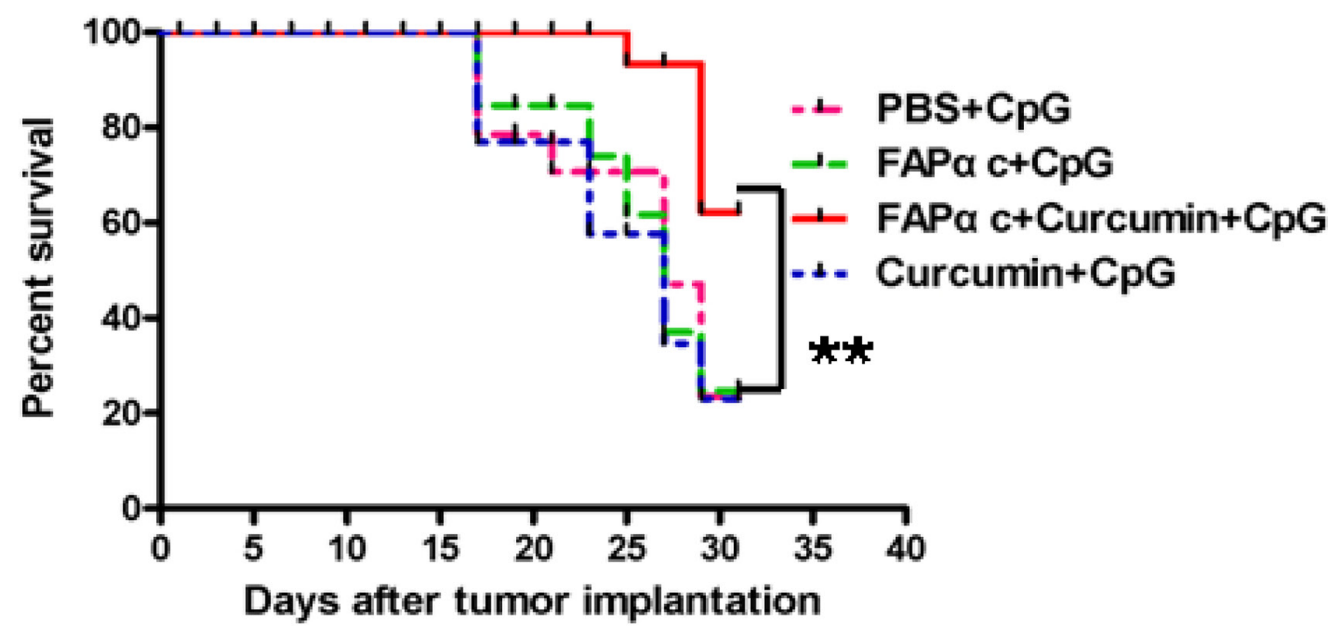

$\mathbf{B}$

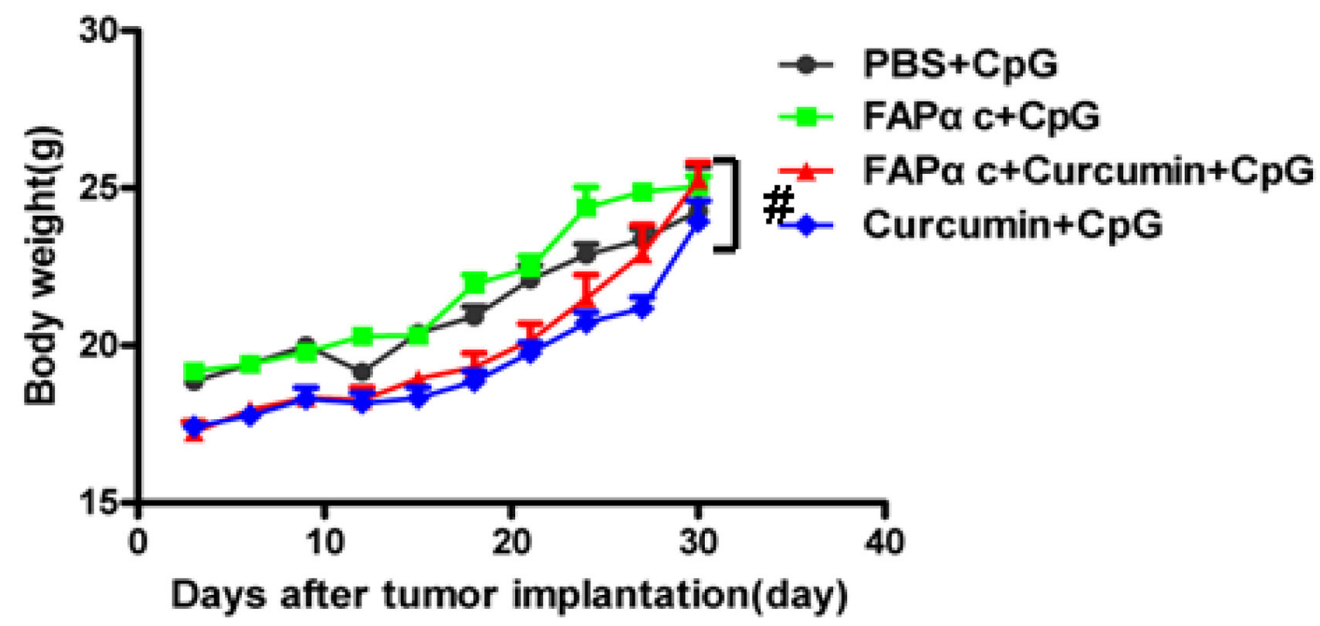

C

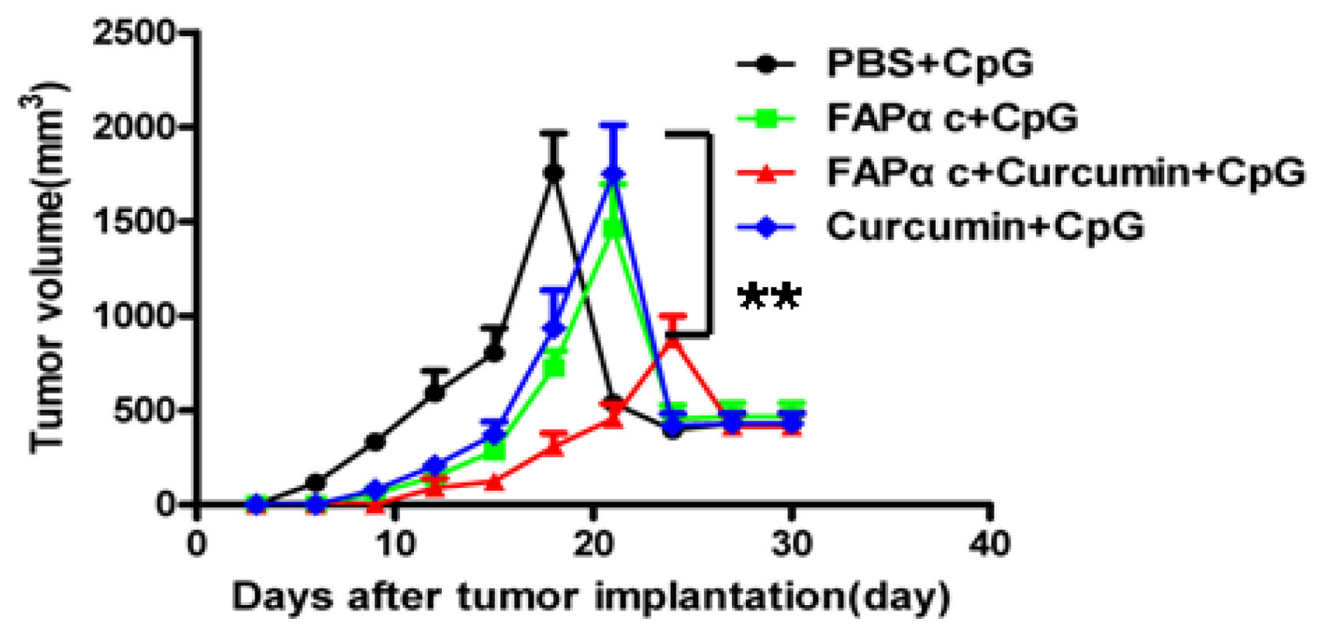

Figure 5: FAPac vaccine plus curcumin and $\mathrm{CpG}$ elicited a protective antitumor response in B16 tumor-bearing mice. B16 tumor cells were implanted (s.c.) in the backs of B57 mice after the second immunization, after which tumor volumes and body weights were measured at regular intervals. A. Survival rate among mice treated during the experiment. Thirty-one days after tumor implantation, the survival rate among mice immunized with FAP $\alpha c+$ curcumin $+\mathrm{CpG}$ is significantly higher than among mice immunized with $\mathrm{PBS}+\mathrm{CpG}, \mathrm{FAP} \alpha \mathrm{c}+\mathrm{CpG}$ or curcumin $+\mathrm{CpG}(* * p<0.01)$. B. Average body weights of the mice in the different groups did not differ during the experiment $(\# p>0.05)$. C. Tumor growth $(n=10)$. Following vaccination, tumors were measured every 3 days $(\mathrm{mean} \pm \mathrm{SE})$ as described in the Materials and Methods. Tumor volume in mice immunized with FAP $\alpha c+$ curcumin $+\mathrm{CpG}$ were significantly smaller than in the other three groups $\left({ }^{* *} p<0.01\right)$. 

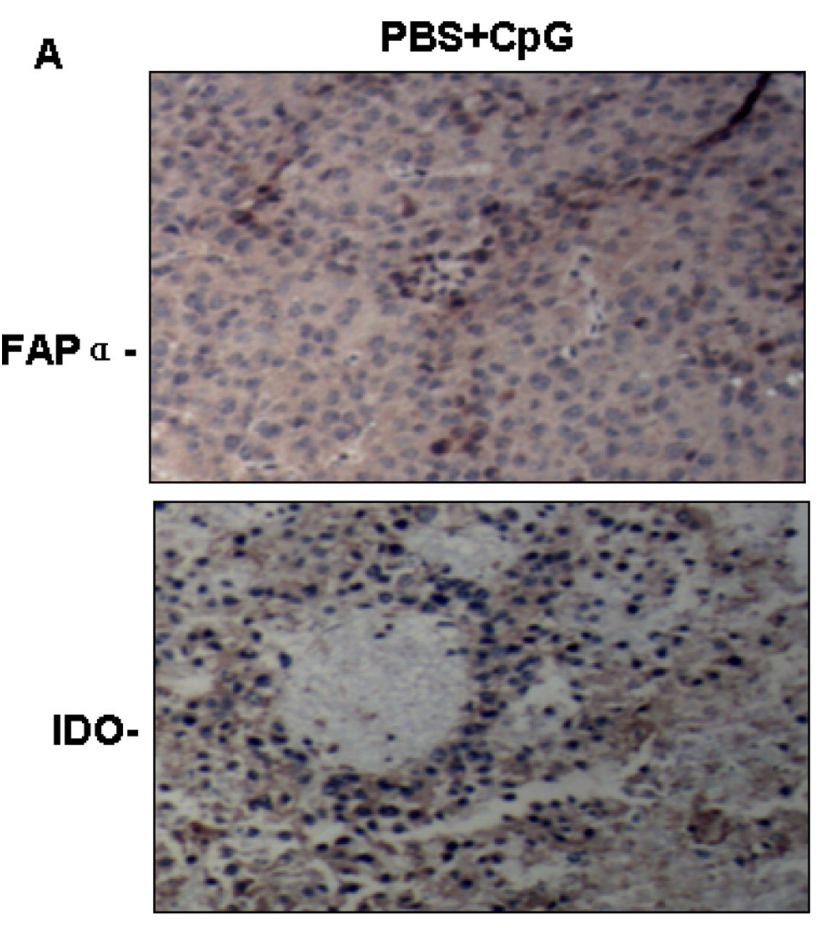

C
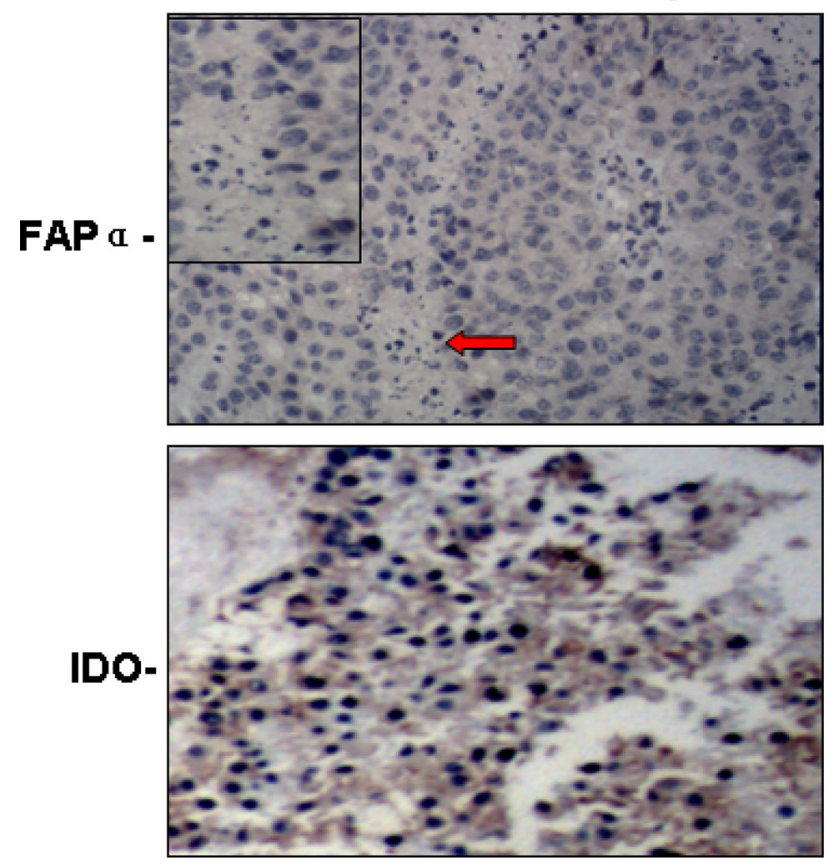
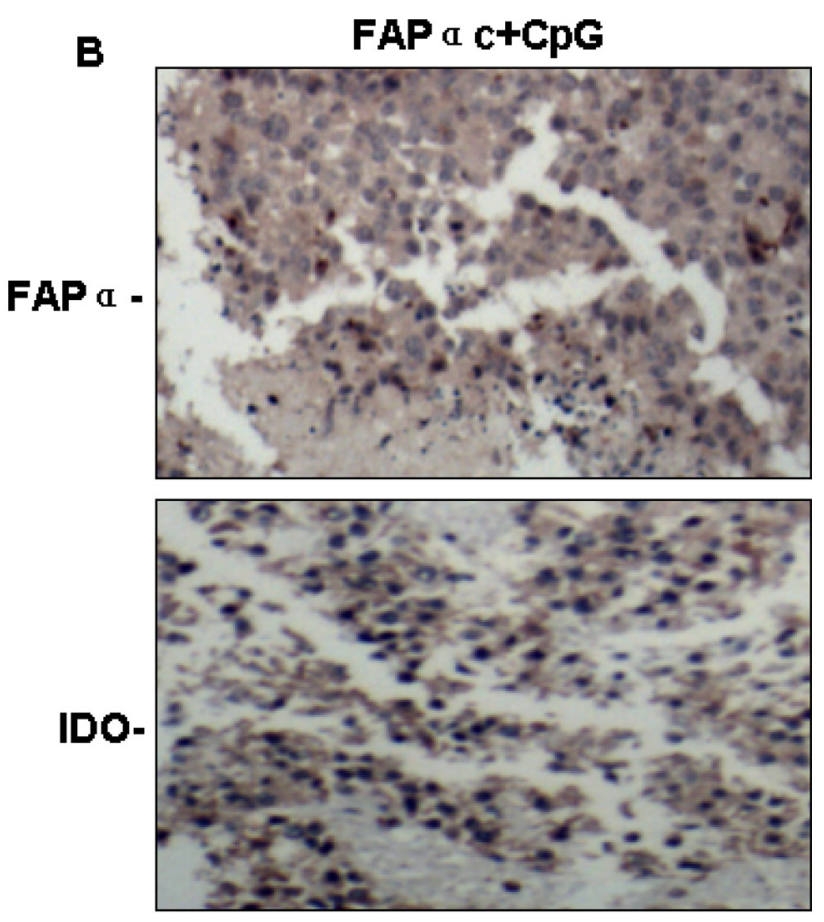

D Curcumin+cpg
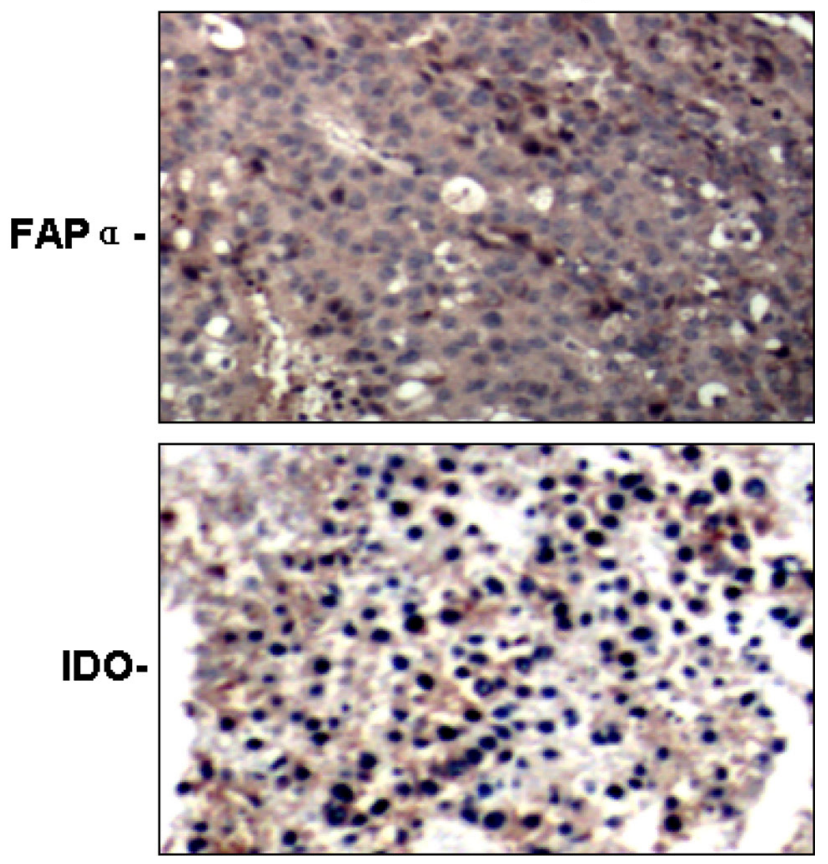

Figure 6: Effect of curcumin and FAPac vaccine on expression of FAP $\alpha$ and IDO in B16 tumor-bearing mice. Mice were assigned to four groups as follows, $\mathrm{PBS}+\mathrm{CpG} \mathbf{A}$. FAP $\alpha+\mathrm{CpG}$ B. FAP $\alpha c+$ curcumin $+\mathrm{CpG}$ C. Curcumin $+\mathrm{CpG}$ D. after which the distributions of IDO and FAP $\alpha$ in tumor tissue were examined immunohistochemically.

through down-regulation of NF- $\mathrm{BB} /$ Snail signaling [32]. Given that TNF- $\alpha$ induces EMT and promotes metastasis via NF-kB-mediated Twist expression [33], we speculate that curcumin may inhibit TNF- $\alpha$-induced EMT in B16 cells by inhibiting NF-kB-dependent signaling, though that idea remains to be tested. The properties of curcumin appear to make it an ideal agent for combination with tumor vaccines for antitumor therapy. In addition, we previously observed that adding $\mathrm{CpG}$ to the vaccine dramatically enhances the vaccine's antitumor efficacy [21]. Taken 

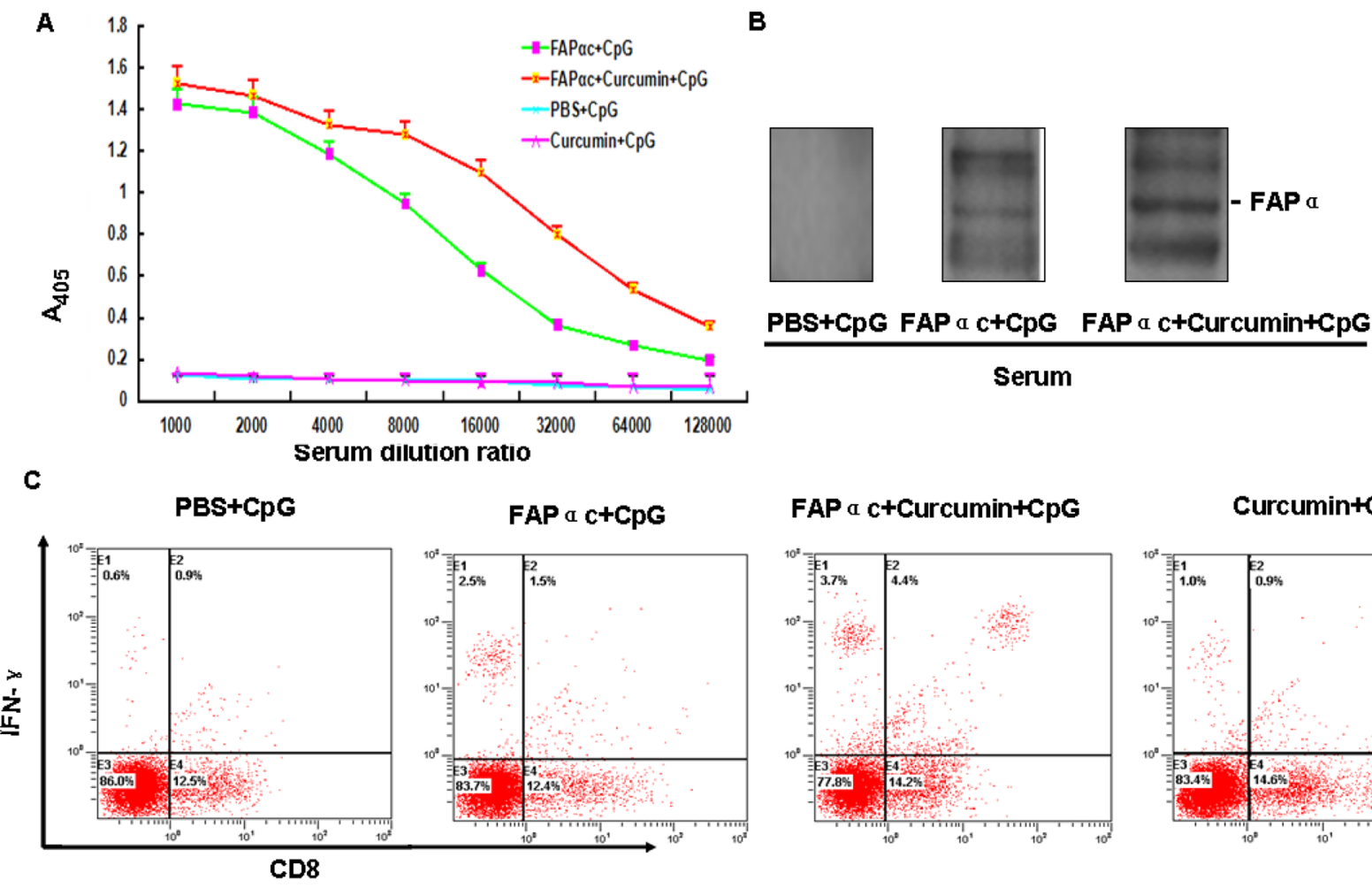

FAP a c+Curcumin+CpG

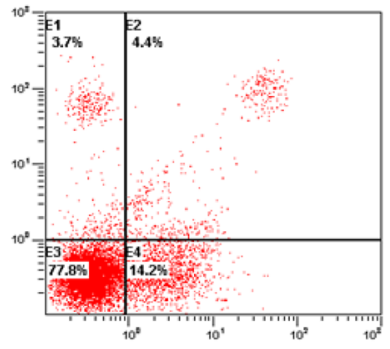

Curcumin+CpG

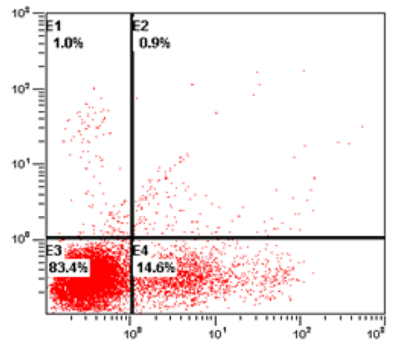

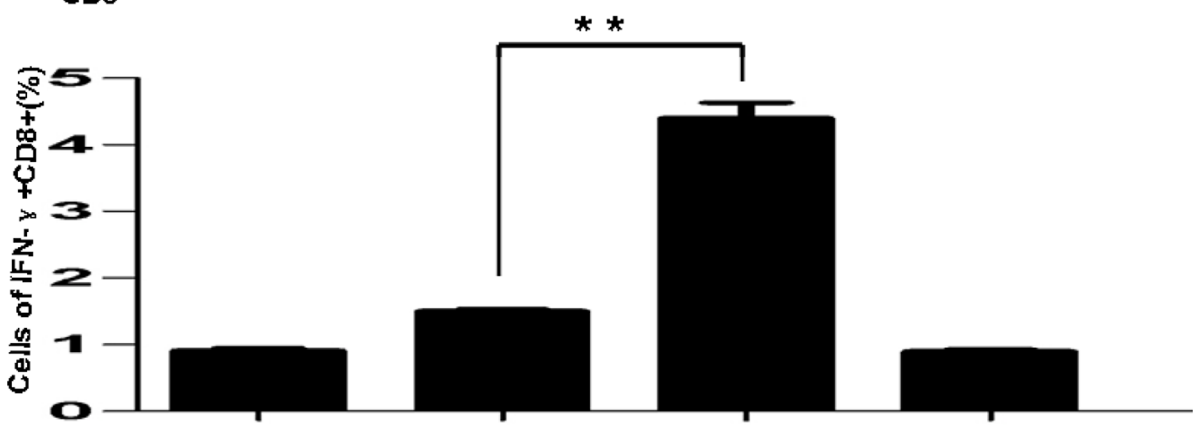

PBS+Cpg FAP a c+CpG FAP a $c+$ Curcumin+Cpg Curcumin+CpG

Figure 7: Detection of immune responses in B16 tumor-bearing mice. A. Results of ELISAs using an anti-FAP $\alpha$ antibody. Mice were vaccinated as described in Materials and Methods. One week after the second booster, the serum samples were collected for detection of anti-FAP $\alpha$ antibody using the ELISA. B. Western blotting analysis of the serum anti-FAP $\alpha$ antibody specificity. The antigen was the lysate from tumor tissue from B16 tumor-bearing mice. C. Detection of CD8+ T cell function. On day 47, when the experiment was terminated, splenocytes were isolated and re-stimulated with FAP $\alpha \mathrm{c}$ ex vivo. IFN- $\gamma$ production in CD8+ T cells was then assessed using flow cytometry, ${ }^{* *} p<0.01$.

together, these results suggest combining FAPac, curcumin and $\mathrm{CpG}$ could be a potentially effective approach to treating melanoma (Figure 5).

In sum, our findings suggest a FAP ac vaccine in combination with curcumin is a promising therapeutic strategy for the treatment of melanoma. This approach is associated with three beneficial effects: First, it breaks tumor tolerance and activates tumor-responsive $\mathrm{T}$ cells through inhibition of IDO expression. Second, because cancer cells depend on stromal cells for support through paracrine stimulation, targeting stromal cells may increase the susceptibility of melanoma cells to both immunological and pharmacological antitumor therapy (Figure 6). Finally, curcumin inhibits TNF- $\alpha$-induced EMT, thereby suppressing the invasiveness and metastatic potential of melanoma cells. We therefore conclude that combined administration of FAP $\alpha c$ vaccine with curcumin may be a new and effective method for preventing and/or treating melanoma.

\section{MATERIALS AND METHODS}

\section{Chemicals and reagents}

Curcumin, hematoxylin, Freund's incomplete adjuvant, mouse TNF- $\alpha$ and IFN- $\gamma$ were purchased from Sigma-Aldrich (Deisenhofen, Germany). The monoclonal 
FAP $\alpha$ antibody was from Abcam, and the monoclonal IDO antibody was from Chemicon. The monoclonal antivimentin antibody, polyclonal anti- $\beta$-actin and secondary HRP-conjugated anti-mouse antibody were from Cell Signaling Technology (MA, USA). The anti-CD8-PE and anti-IFN- $\gamma$-FITC were from Beckman Coulter, and IL-2 and Brefeldin A were from BioLegend.

\section{Cell line and mouse}

B16 (ATCC ${ }^{\circledR}$ CRL-6475 ${ }^{\mathrm{TM}}$ ) cells were cultured in RPMI 1640 (Gibco, Germany) containing 10\% fetal calf serum (Gibco, Germany). C57 mice were purchased from the Sun Yat-sen University (Guangzhou, China) animal center and raised under pathogen-free conditions. All animal studies were conducted in accordance with institutional guidelines for the care and use of experimental animals.

\section{Preparation of FAPac}

We chose the main catalytic domain of the dipeptidyl peptidase of murine FAP $\alpha$ (AA599-AA696) (NP 032012.1), which contains abundant T-cell and B-cell epitopes. The target gene (mRNA 1967-2258, GenBank: BC019190.1) was obtained by RT-PCR and ligated with a prokaryotic expression vector, pET28a $(+)$ (Novagen, Germany), which was then amplified in E. Coli DH5 $\alpha$ and expressed in E. coli BL21 (DE3). The purified peptide (FAP $\alpha$ c) was employed as the FAP $\alpha$ vaccine.

\section{Cytotoxicity assay}

The cytotoxicity of curcumin toward the cultured cells was assessed using MTT [3-(4, 5-dimethylthiazol2yl)-2, 5-diphenyltetrazolium bromide] assays (Sigma Chemical Co., USA). B16 cells were seeded onto 96-well microplates (NunC, Denmark) at a density of $1 \times 10^{4}$ cells per well and incubated for $24 \mathrm{~h}$. The Cells were then treated with selected concentrations of curcumin for $24 \mathrm{~h}$ or $48 \mathrm{~h}$. Cells in culture medium alone served as the untreated control. The MTT reagent $(5 \mathrm{mg} / \mathrm{ml}$ in distilled water) was prepared immediately prior to use. After removing the incubation medium from the wells, the cells were washed with phosphate-buffered saline (PBS) and $10 \mathrm{ml}$ of MTT reagent was added. After incubation for $4 \mathrm{~h}$ at $37^{\circ} \mathrm{C}$, MTT reagent in $100 \mathrm{ml}$ of dimethylsulfoxide (DMSO) was added to each well. Surviving cells were then detected by measuring absorbance at $570 \mathrm{~nm}$ using a plate reader. The cell viability was expressed as a percentage of the values obtained for the controls.

\section{Western blotting analysis}

Cells were lysed in lysis buffer, after which the lysates were cleared by centrifugation and denatured by boiling in Laemmli buffer. Aliquots of protein samples were then separated on $12 \%$ sodium dodecyl sulfate
(SDS)-polyacrylamide gels and electrophoretically transferred to nitrocellulose membranes. After blocking with $5 \%$ non-fat milk at room temperature for $2 \mathrm{~h}$, the membranes were incubated first with the primary antibody at $1: 1000$ dilution overnight at $4^{\circ} \mathrm{C}$, and then with a HRPconjugated secondary antibody at 1:5000 dilution for $1 \mathrm{~h}$ at room temperature. Specific immune complexes were detected using western blotting plus chemiluminescence reagent (Life Science, Inc., Boston, MA).

\section{Adjuvant and vaccine preparation}

The phosphorothioate-modified $\mathrm{CpG}$ oligonucleotide 1,826 (5'-TCCATGACGTTCCTGACGTT-3') was synthesized by the Shanghai Sangon Biological Engineering Technology and Service. The antigens FAP $\alpha$ c and $\mathrm{CpG}$ were separately dissolved in PBS. The two solutions were mixed to obtain a suspension including $200 \mu \mathrm{g}$ (first vaccine per mouse) or $100 \mu \mathrm{g}$ antigens FAP $\alpha \mathrm{c}$ and $30 \mu \mathrm{g} \mathrm{CpG}$. Then the suspension was emulsified by equivalent volume of Freund's incomplete adjuvant.

\section{Immunization and measurement of tumor growth}

Five-week-old female C57 mice were randomly assigned into four groups, and immunized (s.c.) on the back in multiple locations on days 0,14 and 21 (Figure 1). The groupings were as follows: $1(n=10), 30 \mu \mathrm{g} \mathrm{CpG}$ (per mouse); $2(n=10), 200 \mu \mathrm{g}$ FAP $\alpha \mathrm{c}$ and $30 \mu \mathrm{g} \mathrm{CpG}$; $3(n=10), 200 \mu \mathrm{g}$ FAP $\alpha \mathrm{c}, 30 \mu \mathrm{g} \mathrm{CpG}$ and curcumin (administration was initiated with the first immunization and ended 10 days after the last immunization; dissolved in $1 \%$ Tween $80 / 0.5 \%$ methylcellulose at a concentration of $50 \mathrm{mg} / \mathrm{ml}, 5 \mathrm{mg}$ once/day) with additional lavage using intragastric administration needles $(0.9 \times \mathrm{L} 50 \mathrm{~mm})$; $4(n=10)$, curcumin and $30 \mu \mathrm{g} \mathrm{CpG}$. On day 17 , tumors were implanted through injection of B16 cells $\left(10^{5}\right.$ cells $)$ into the backs of the mice. Tumor growth and body weights were measured every three days, and the tumor volumes were determined using the formula $\left(a \times b^{2}\right) / 2$, where $a$ is the larger and $b$ the smaller diameter. The experiment was terminated on day 47.

\section{Immunohistochemical detection of FAPa and IDO expression}

Tumors were harvested and then fixed in $4 \%$ paraformaldehyde, after which 5 - $\mu$ m paraffin-embedded sections were cut. This was followed by deparaffinization, antigen retrieval, serum blocking and incubation with antiFAP $\alpha$ antibody (1:100 dilution) or anti-IDO antibody (1:50 dilution) overnight at $4^{\circ} \mathrm{C}$. An isotype-matched irrelevant antibody was used as the negative control. After washing, slides were incubated with HRP IgG (EnVision+; DAKO), and DAB (DAKO) was applied as a substrate. Lastly, the slides were counterstained with hematoxylin. 


\section{Measurement of serum FAP $\alpha$ antibody using ELISA}

Blood samples were obtained via the tail vein from each mouse, and serum was collected. After precoating 96-well plates with FAP $\alpha c$ antigen $(100 \mathrm{ng} / \mathrm{well})$ and blocking with 3\% bovine serum albumin for $1 \mathrm{~h}$ at room temperature, the serum samples were added in serial dilutions from $1: 1000$ to $1: 128,000$. The plates were then washed, and HRP-conjugated IgG (1:5000 dilution; Boster) was added for $1 \mathrm{~h}$ at room temperature. The plates were then washed, and the signals were developed using tetramethylbenzidine and hydrogen peroxide and were read at $\mathrm{A}_{405}$ using an Elx800 universal microplate reader (Bio-Tek).

\section{Detection of CD8+ T-cell function in the spleens of tumor bearing mice}

Spleens were collected 31 days after tumor implantation. Freshly isolated splenocytes were incubated in ammonium chloride buffer to lyse the erythrocytes and then stimulated with $10 \mu \mathrm{g} / \mathrm{ml}$ FAP $\alpha c$. IL-2 and Brefeldin A were added at concentrations of $300 \mathrm{U} / \mathrm{ml}$ and $1 \mu \mathrm{g} /$ $\mathrm{ml}$, respectively. After stimulation for 3 days, the cells were collected, stained with PE-CD8 and FITC-IFN- $\gamma$ antibodies, and detected using flow cytometry.

\section{Statistical analyses}

All values are reported as the mean $\pm \mathrm{SEM}$ of three independent experiments unless otherwise specified. Comparisons between two groups were analyzed using two-tailed unpaired Student's $t$ test, and one-way ANOVA followed by Bonferroni's test was used for multiple comparisons. These analyses were performed using Prism Software Version 5.0 (GraphPad Software Inc., La Jolla, CA). Values of $p<0.05$ was considered statistically significant.

\section{ACKNOWLEDGMENTS AND FUNDING}

Grant support: This work was funded by the Hunan Natural Science Foundation (No. 13JJ4078), the Bureau of Hunan Provincial Science and Technology (No. 2013sk5010, No. 2012sk2007, No. 2012sk3252), the National Program on Key Basic Research Project (973 Program) (NO. 2011CB935800), the National Natural Science Foundation of China (No. 81472470, No. 81302317, and No. 31101071), the Guangdong Natural Science Funds for Distinguished Young Scholar (No. 2014A030306025), the Fundamental Research Funds for the Central Universities (Sun Yat-sen University) (No. 12ykpy09) and the Science and Technology Planning Project of Guangdong Province, China (No. 2012B031500005).

\section{CONFLICTS OF INTEREST}

No potential conflicts of interest were disclosed.

\section{REFERENCES}

1. Tsai KK, Zarzoso I, Daud AI. PD-1 and PD-L1 antibodies for melanoma. Human vaccines \& immunotherapeutics. 2014; 10:3111-3116.

2. Hodi FS, O'Day SJ, McDermott DF, Weber RW, Sosman JA, Haanen JB, Gonzalez R, Robert C, Schadendorf D, Hassel JC, Akerley W, van den Eertwegh AJ, Lutzky J, Lorigan P, Vaubel JM, Linette GP, et al. Improved survival with ipilimumab in patients with metastatic melanoma. The New England journal of medicine. 2010; 363:711-723.

3. Mellor AL, Munn DH. IDO expression by dendritic cells: tolerance and tryptophan catabolism. Nature reviews Immunology. 2004; 4:762-774.

4. Takikawa O. Biochemical and medical aspects of the indoleamine 2, 3-dioxygenase-initiated L-tryptophan metabolism. Biochemical and biophysical research communications. 2005; 338:12-19.

5. Jiang GM, He YW, Fang R, Zhang G, Zeng J, Yi YM, Zhang S, Bu XZ, Cai SH, Du J. Sodium butyrate downregulation of indoleamine 2, 3-dioxygenase at the transcriptional and post-transcriptional levels. The international journal of biochemistry \& cell biology. 2010; 42:1840-1846.

6. Uyttenhove C, Pilotte L, Theate I, Stroobant V, Colau D, Parmentier N, Boon T, Van den Eynde BJ. Evidence for a tumoral immune resistance mechanism based on tryptophan degradation by indoleamine 2, 3-dioxygenase. Nature medicine. 2003; 9:1269-1274.

7. Hou DY, Muller AJ, Sharma MD, DuHadaway J, Banerjee T, Johnson M, Mellor AL, Prendergast GC, Munn DH. Inhibition of indoleamine 2, 3-dioxygenase in dendritic cells by stereoisomers of 1-methyl-tryptophan correlates with antitumor responses. Cancer research. 2007; 67:792-801.

8. Ohshio Y, Teramoto K, Hanaoka J, Tezuka N, Itoh Y, Asai T, Daigo Y, Ogasawara K. Cancer-associated fibroblast-targeted strategy enhances antitumor immune responses in dendritic cell-based vaccine. Cancer science. 2015; 106:134-142.

9. Kelly T, Huang Y, Simms AE, Mazur A. Fibroblast activation protein-alpha: a key modulator of the microenvironment in multiple pathologies. International review of cell and molecular biology. 2012; 297:83-116.

10. Rettig WJ, Garin-Chesa P, Beresford HR, Oettgen HF, Melamed MR, Old LJ. Cell-surface glycoproteins of human sarcomas: differential expression in normal and malignant tissues and cultured cells. Proceedings of the National Academy of Sciences of the United States of America. $1988 ; 85: 3110-3114$. 
11. Scott AM, Wiseman G, Welt S, Adjei A, Lee FT, Hopkins W, Divgi CR, Hanson LH, Mitchell P, Gansen DN, Larson SM, Ingle JN, Hoffman EW, Tanswell P, Ritter G, Cohen LS, et al. A Phase I dose-escalation study of sibrotuzumab in patients with advanced or metastatic fibroblast activation protein-positive cancer. Clinical cancer research 2003; 9:1639-1647.

12. Jackson RC. Contributions of protein structure-based drug design to cancer chemotherapy. Seminars in oncology. 1997; 24:164-172.

13. Kraman M, Bambrough PJ, Arnold JN, Roberts EW, Magiera L, Jones JO, Gopinathan A, Tuveson DA, Fearon DT. Suppression of antitumor immunity by stromal cells expressing fibroblast activation protein-alpha. Science. 2010; 330:827-830.

14. Munn DH, Mellor AL. Indoleamine 2, 3-dioxygenase and tumor-induced tolerance. The Journal of clinical investigation. 2007; 117:1147-1154.

15. Yu L, Mu Y, Sa N, Wang H, Xu W. Tumor necrosis factor alpha induces epithelial-mesenchymal transition and promotes metastasis via NF-kappaB signaling pathwaymediated TWIST expression in hypopharyngeal cancer. Oncology reports. 2014; 31:321-327.

16. Wang H, Fang R, Wang XF, Zhang F, Chen DY, Zhou B, Wang HS, Cai SH, Du J. Stabilization of Snail through AKT/GSK-3beta signaling pathway is required for TNFalpha-induced epithelial-mesenchymal transition in prostate cancer PC3 cells. European journal of pharmacology. 2013; 714:48-55.

17. Xue C, Plieth D, Venkov C, Xu C, Neilson EG. The gatekeeper effect of epithelial-mesenchymal transition regulates the frequency of breast cancer metastasis. Cancer research. 2003; 63:3386-3394.

18. Jiang GM, Wang HS, Zhang F, Zhang KS, Liu ZC, Fang R, Wang H, Cai SH, Du J. Histone deacetylase inhibitor induction of epithelial-mesenchymal transitions via up-regulation of Snail facilitates cancer progression. Biochimica et biophysica acta. 2013; 1833:663-671.

19. Maheshwari RK, Singh AK, Gaddipati J, Srimal RC. Multiple biological activities of curcumin: a short review. Life sciences. 2006; 78:2081-2087.

20. Yao QY, Xu BL, Wang JY, Liu HC, Zhang SC, Tu CT. Inhibition by curcumin of multiple sites of the transforming growth factor-betal signalling pathway ameliorates the progression of liver fibrosis induced by carbon tetrachloride in rats. BMC complementary and alternative medicine. 2012; 12:156.

21. Zeng J, Cai S, Yi Y, He Y, Wang Z, Jiang G, Li X, Du J. Prevention of spontaneous tumor development in a ret transgenic mouse model by ret peptide vaccination with indoleamine 2, 3-dioxygenase inhibitor 1-methyl tryptophan. Cancer research. 2009; 69:3963-3970.
22. Callahan MK, Postow MA, Wolchok JD. CTLA-4 and PD-1 Pathway Blockade: Combinations in the Clinic. Frontiers in oncology. 2014; 4:385.

23. Gilboa E. The promise of cancer vaccines. Nature reviews Cancer. 2004; 4:401-411.

24. Erez N, Truitt M, Olson P, Arron ST, Hanahan D. Cancer-Associated Fibroblasts Are Activated in Incipient Neoplasia to Orchestrate Tumor-Promoting Inflammation in an NF-kappaB-Dependent Manner. Cancer cell. 2010; 17:135-147.

25. Garin-Chesa P, Old LJ, Rettig WJ. Cell surface glycoprotein of reactive stromal fibroblasts as a potential antibody target in human epithelial cancers. Proceedings of the National Academy of Sciences of the United States of America. 1990; 87:7235-7239.

26. Lee J, Fassnacht M, Nair S, Boczkowski D, Gilboa E. Tumor immunotherapy targeting fibroblast activation protein, a product expressed in tumor-associated fibroblasts. Cancer research. 2005; 65:11156-11163.

27. Loeffler M, Kruger JA, Niethammer AG, Reisfeld RA. Targeting tumor-associated fibroblasts improves cancer chemotherapy by increasing intratumoral drug uptake. The Journal of clinical investigation. 2006; 116:1955-1962.

28. Niedermeyer J, Scanlan MJ, Garin-Chesa P, Daiber C, Fiebig HH, Old LJ, Rettig WJ, Schnapp A. Mouse fibroblast activation protein: molecular cloning, alternative splicing and expression in the reactive stroma of epithelial cancers. International journal of cancer 1997; 71:383-389.

29. Kelderman S, Schumacher TN, Haanen JB. Acquired and intrinsic resistance in cancer immunotherapy. Molecular oncology. 2014; 8:1132-1139.

30. Ma C, Armstrong AW. Severe adverse events from the treatment of advanced melanoma: a systematic review of severe side effects associated with ipilimumab, vemurafenib, interferon alfa- $2 b$, dacarbazine and interleukin-2. The Journal of dermatological treatment. 2014; 25:401-408.

31. Jeong YI, Kim SW, Jung ID, Lee JS, Chang JH, Lee CM, Chun SH, Yoon MS, Kim GT, Ryu SW, Kim JS, Shin YK, Lee WS, Shin HK, Lee JD, Park YM. Curcumin suppresses the induction of indoleamine 2, 3-dioxygenase by blocking the Janus-activated kinase-protein kinase Cdelta-STAT1 signaling pathway in interferon-gamma-stimulated murine dendritic cells. The Journal of biological chemistry. 2009; 284:3700-3708.

32. Huang T, Chen Z, Fang L. Curcumin inhibits LPS-induced EMT through downregulation of NF-kappaB-Snail signaling in breast cancer cells. Oncology reports. 2013; 29:117-124.

33. Yu L, Mu Y, Sa N, Wang H, Xu W. Tumor necrosis factor alpha induces epithelial-mesenchymal transition and promotes metastasis via NF-kappaB signaling pathwaymediated TWIST expression in hypopharyngeal cancer. Oncology reports. 2014; 31:321-327. 